\title{
МЕТОДОЛОГІЧНІ ОСНОВИ ПРОВЕДЕННЯ ЕКСПЕРИМЕНТАЛЬНО-ФОНЕТИЧНОГО ДОСЛІДЖЕННЯ ФОНОСЕМАНТИЧНИХ КОМПЛЕКСІВ В СУЧАСНОМУ АНГЛОМОВНОМУ ХУДОЖНЬОМУ КІНОДИСКУРСІ
}

\author{
Насікан 3. $\boldsymbol{C}$. \\ Украӥна, Київ, Київський національний лінгвістичний університет, кафедра германської і фіно- \\ угорської філології імені професора Г.Г. Почепщова
}

DOI: https://doi.org/10.31435/rsglobal_ijitss/30042019/6460

\section{ARTICLE INFO}

Received 14 February 2019

Accepted 23 April 2019

Published 30 April 2019

\section{KEYWORDS}

phonosemantics,

phonosemantic means, phonosemantic complexes, acoustic analysis, perceptual analysis.

\begin{abstract}
This paper deals with the methodology of experimental research of phonosemantics complexes that are able to actualize the emotional function in modern English film discourse. It is claimed that such type of investigation must be held by means of perceptual and acoustic analyses. The article contains the program of investigation, its main stages including corpus, participants (auditorsinformants and auditors-phoneticians), and their tasks. Acoustic analysis was directed on proving the results of perceptive analyses by counting and evaluation of tonal, dynamic and temporal characteristics. The given methodological grounds create a fundamental basis for investigation of phonosemantic means and complexes of modern English motion pictures.
\end{abstract}

Citation: Насікан 3. C. (2019) Metodolohichni Osnovy Provedennia Eksperymentalno-Fonetychnoho Doslidzhennia Fonosemantychnykh Kompleksiv v Suchasnomu Anhlomovnomu Khudozhnomu Kinodyskursi. International Journal of Innovative Technologies in Social Science. 3(15). doi: 10.31435/rsglobal_ijitss/30042019/6460

Copyright: (C) 2019 Насікан 3. C. This is an open-access article distributed under the terms of the Creative Commons Attribution License (CC BY). The use, distribution or reproduction in other forums is permitted, provided the original author(s) or licensor are credited and that the original publication in this journal is cited, in accordance with accepted academic practice. No use, distribution or reproduction is permitted which does not comply with these terms.

Мета експериментально-фонетичного методу полягала в окресленні специфіки дослідження фоносемантичних комплексів в емоційному мовленні сучасного англомовного художнього кінодискурсу та визначенні їх взаємозв'язку із засобами інших мовних рівнів. Результати дослідження та їх виклад чітко співвідносяться із класифікацією фоносемантичних комплексів РУХ, ФІЗИЧНІ ВИМІРИ та НАСТРІЙ, що стало підгрунтям для виконання основних завдань дисертаційної праці.

Перш за все, доцільно зауважити, що програма та методика зазначені у нашій роботі спиралися на фундаментальні праці відомих мовознавців (Багмут, Борисюк, Олійник, 1980; Цеплітіс, 1974; Нушикян, 1986; Калита, 2007; Хейвард, 2013) присвячені проведенню експериментально-фонетичних досліджень, які і склали надійний науковий фундамент та неодноразово апробуються у сучасних лінгвістичних студіях.

Програма експериментально-фонетичного дослідження мала чітко визначену послідовність дій, яка включала в собі такі етапи: 1) формування експериментального матеріалу; 2) підбір дикторів та запис певного корпусу матеріалу; 3) підбір інформантів; 4) аудитивний аналіз аудиторами-інформантами англомовних висловлень із кіно- та мультиплікаційних фільмів; 5) аудитивний аналіз фонетистами-експертами англомовних висловлень із кіно- та мультиплікаційних фільмів; 6) акустичний аналіз динамічних, тональних та темпоральних параметрів висловлень експериментального матеріалу; 7) лінгвістична інтерпретація результатів експериментального дослідження, підведення його підсумків та висновків. 
Для аналізу та вивчення всього арсеналу фоносемантичних засобів та їхніх комплексів, які здатні реалізувати емоційну функцію, перший етап нашого дослідження був сконцентрований навколо формування самого корпусу експериментального матеріалу. Для цього ми відібрали 10 кіно- та мультиплікаційних фільмів різної жанрової приналежності (пригоди, драма, мелодрама, сімейний, трилер тощо). Багатовекторність жанрів була нами обрана не випадково, оскільки таким чином ми хотіли показати наявність фоносемантичних комплексів незалежно від жанру і цим самим показати, що вони є невід'ємним атрибутом будь якого мовлення, емоційного зокрема. Тобто таким чином ми зробили спробу показати їхню універсальність. Отже, нами було обрано 3 мультиплікаційні фільми та 7 кінофільмів із загальною тривалістю 18 годин 29 хвилин 29 секунд. Перелік фільмів, що складали експериментальний корпус подано у таблиці 1:

Таблиця 1. Список кіно- та мультиплікаційних фільмів, що увійшли в корпус експериментального дослідження

\begin{tabular}{|c|c|c|c|c|}
\hline № & $\begin{array}{c}\text { Назва фільму } \\
\text { англійською }\end{array}$ & Назва українською & Рік & Жанр \\
\hline 1 & Brave & Відважна & 2012 & мультфільм, сімейний \\
\hline 2 & The Holliday & Відпочинок за обміном & 2006 & мелодрама \\
\hline 3 & Doctor Strange & Доктор Стрендж & 2016 & фентезі, пригоди, екшн \\
\hline 4 & $\begin{array}{c}\text { Confessions of a } \\
\text { shopaholic }\end{array}$ & Зізнання шопоголика & 2009 & романтична, комедія, сімейний \\
\hline 5 & Pocahontas & Покахонтас & 1995 & мультфільм, драма \\
\hline 6 & Hacksaw Ridge & З міркувань совісті & 2016 & військово-історична драма, \\
\hline 7 & $\begin{array}{c}\text { бhe Princess and the } \\
\text { Frog }\end{array}$ & Принцеса і жабеня & 2009 & мультфільм, пригоди \\
\hline 8 & Stardust & Зоряний пил & 2007 & фентезі, сімейний \\
\hline 9 & The girl on the train & Дівчина у потягу & 2016 & кримінал, драма, трилер \\
\hline 10 & A Series of & Лемоні Снікет: 33 & 2004 & пригоди, сімейний \\
\hline
\end{tabular}

Із зазначеного списку фільмів було виокремлено низку діалогічних та монологічних висловлень, в яких було відмічено прямий взаємозв'язок плану змісту та плану форми, що реалізувався за допомогою фоносемантичних засобів, які організовували цілі фоносемантичні комплекси. Дослідження проводилося на персональному комп'ютері ASUS (процесор Intel (R) Pentium (R) CPU 987@, тактова частота 1,50 Ггц, оперативна пам'ять 4 Г, жорсткий диск 258 Г). Ліцензовані версії фільмів були придбані за допомогою програми Google Play Movies. Після завантаження усіх фільмів на комп'ютер, вони були прочитані програмою Sony Movie Studio Platinum 13.0 з метою вилучення необхідних звукових доріжок формату *.wav та відповідних їм відео доріжок у форматі *.mp4. Тому сегментація шляхом зазначеної вище програми уможливила підготувати необхідні висловлення та сформувати таким чином експериментальний корпус для аналізу його аудиторами-інформантами, аудиторамифонетистами та акустичного аналізу сучасними комп'ютерними мультимедійними програмами.

Для подальшого вивчення просодичних особливостей фоносемантичних комплексів емоційного мовлення, нами було вирішено провести запис обраних висловлень дикторами у кількості 6 осіб (3 жінки і 3 чоловіки). Всі диктори мають вищу освіту та володіють орфоепічною нормою британського та американського варіанту англійської мови. Завдання учасників полягало у нейтральному зачитуванні 28 запропонованих фрагментів. Диктори не були проінформовані про джерела уривків і зачитували їх ізольовано, без знання контексту. Запис проводився на диктофон на мобільний пристрій Samsung-G360H у форматі *.wav 3 подальшим копіюванням аудіо файлів на комп'ютер для проведення їх інструментального аналізу за допомогою сучасних акустичних програм. Результатом цього етапу стали по 28 пар висловлень однакові за лексико-граматичною будовою, проте різні за фонетичним оформленням. Це дало можливість виявити специфіку формування фоносемантичних засобів та комплексів саме в емоційному мовленні, що є ознакою всіх кінострічок та мультфільмів. 
Відповідно до методики нашого експериментально-фонетичного дослідження, та необхідності адекватного оцінювання фрагментів із фільмів, наступним кроком стало залучення 5 аудиторів-інформантів, носіїв літературної норми англійської мови, віком від 2355 років, які мали гуманітарну вищу освіту. Аудиторам-респондентам було запропоновано переглянути низку відео фрагментів із зазначених нами кіно- та мультиплікаційних фільмів та дати відповіді на запитання. Попередньо, з учасниками експерименту була проведена бесіда, в ході якої їм були пояснені їхні завдання для виконання. Перебіг цього етапу та всіх наступних обов'язково фіксувалися у робочих протоколах.

Відтак аудитори-інформанти мали переглянути 15 епізодів фільмів, обсяг кожного 3 яких сягав не більше 1 хвилини. Також респондентам були надані роздруковані матеріали, які містили: а) список фільмів, назву англійською мовою, назву українського дубляжу, роком випуску, режисером та жанром); б) короткий огляд загального сюжету та конкретного епізоду, який виносився на аналіз; в) анкета, для внесення персональних даних та відповідей на запитання до фільмів. Завдання учасників експерименту полягало у визначенні, чи епізод був емоційно насиченим; якщо відповідь була позитивна, то аудитор переходив до наступного питання, де треба було розділити емоції, які переважали у головних героїв епізоду (позитивні, негативні чи нейтральні). Наступне завдання стосувалося вже безперечно лінгвістичного наповнення, а саме виявлення мовних (фонетичних, граматичних, лексичних та невербальних) засобів у фрагменті, які сприяли створенню емоційно забарвленого мовлення. Останнє завдання полягало в узагальнені основного значення фрагменту та віднесення його до запропонованих класів денотатів таких, як РУХ (вгору, вниз, уповільнений тощо), ФІЗИЧНІ ВИМІРИ (великий, малий, широкий, вузький тощо) та НАСТРІЙ (сумний, піднесений тощо), що стало основою нашої класифікації фоносемантичних комплексів. Запропоновані аудиторами типи або класи денотатів теж враховувалися у дослідженні та фіксувалися у протоколах. Кількість прослуховувань для респондентів була довільна.

За результатами першого етапу аудитивного аналізу було сформовано матеріал для подальшого аналізу його аудиторами-фонетистами. Для цього етапу ми залучили 5 аудиторів не носіїв англійської мови, які є експертами у галузі фонетики, мають достатній досвід експериментально-фонетичного аудіювання та можуть надати фахову оцінку поданим фрагментам. Аналогічно до попереднього етапу, з аудиторами-фонетистами була проведена бесіда в якій обговорювались їхні основні завдання. Хід цього етапу, як і всіх попередніх теж ресструвався у робочому протоколі.

Аналіз перцептивних характеристик аудиторами-фонетистами передбачав виконання ними таких завдань: 1) поділ висловлень на синтагми та ритмогрупи 3 позначенням пауз відповідними позначками; 2) позначення логічного та емоційного наголосу; 3) оцінювання тональних параметрів, а саме типу термінального тону, тонального рівня початку та завершення шкали, типу мелодійної шкали, тонального діапазону шкали та інтервалу; 4) визначення рівня гучності; 5) оцінювання темпоральних характеристик, а саме різновиду темпу та ритму. Основою переліку просодичних ознак був опис номенклатури інтонаційних характеристик обгрунтованих у праці Калити А. А. (1984). Аудитори-фонетисти не обмежувались у кількості прослуховувань.

Враховуючи той факт, що аудитивний аналіз носить доволі суб'єктивний характер, для всебічного на всеохоплюючого дослідження фоносемантичних засобів та комплексів, які реалізують емоційну функцію інтонації, системною методикою експериментально-фонетичного дослідження було передбачено провести акустичний аналіз як наступний крок. Це сприяло об'єктивній перевірці результатів попереднього етапу шляхом проведення аналізу акустичних характеристик висловлень із зафіксованими в них фоносемантичними комплексами, такими як РУХ, ФІЗИЧНІ, ВИМІРИ та НАСТРІЙ.

Використання таких сучасних програм як Cool Edit Pro, Praat, SFS/WASP та Speech Analyzer дозволяють отримати релевантні показники декількох показників одночасно. Крім того, вони допомагають знайти спільні та розбіжні параметри у різних відрізках в емоційному мовленні та мовленні дикторів. Завдяки цьому стало можливим встановити такі тональні ознаки як: 1) частотний діапазон, для вимірювання якого співвідносяться значення найвищого та найнижчого рівня ЧОТ з подальшим переведенням у півтони та відповідно у відсотки; 2) величина тонального максимуму, що обчислюється через співвідношення максимального 
ЧОТ аналізованої синтагми до усередненого мінімального ЧОТ мовця; 3) величина інтервалів, тобто різниця значень максимального та мінімального рівнів на стиках функціональних ділянок “передтакт-такт”, “1РГ - 2РГ”, “2РГ - ЗРГ ”, “Шкала - Ядро”, “Ядро - Затак””; 4) локалізація тонального максимумів та мінімумів кожної аналізованої синтагми; 5) швидкість зміни ЧОТ; 6) конфігурація та крутизна ЧОТ, яка вимірюється шляхом візуального аналізу.

Дослідження динамічних характеристик англомовних висловлень 3 фоносемантичними комплексами включало: 1) локалізація максимуму інтенсивності з диференціацією контрастів; 2) діапазон інтенсивності, який визначається різницею максимального та мінімального рівнів.

Розгляд темпоральних параметрів дозволив охарактеризувати наступні ознаки: 1) середньозвукова тривалість синтагми; 2) вимірювання тривалості різних видів пауз. Для зручності та подальшої інтерпретації, всі результати акустичного аналізу вносилися у відповідні файли програми Microsoft Excel у вигляді таблиць із абсолютними та відносними значеннями.

Враховуючи особливості нашого дослідження, результати дослідження були подані у у вербальній та графічній формах у вигляді таблиць, діаграм та графіків представлених у додатках.

Узагальнюючи викладене, обрана програма та методика дослідження уможливили проведення повноцінного експериментально-фонетичного дослідження. Його організація та проведення грунтувалося на загальноприйнятих методиках проведення такого роду експериментів, що дало можливість отримати адекватні результати, оскільки вони комплексно включали в собі і суб'єктивний метод (аудитивний аналіз аудиторами-інформантами та аудиторами-фонетистами), і об’єктивний метод (залучення новітніх комп'ютерних акустичних програм). У комплексі ці обидва методи здатні надати повноцінну та систематичну оцінку, інтерпретацію результатів та підвести остаточні підсумки.

\section{ЛІТЕРАТУРА}

1. Багмут, А. Й., Борисюк, І. В. \& Олійник, Г. П. (1980). Інтонація як засіб мовної комунікаиї. Наукова Думка.

2. Блохина, Л. П., \& Потапова, Р. К. (1982). Методика анализа просодических характеристик речи. М.: МГПИИЯ.

3. Калита, А. А. (2007). Актуалізація емоційно-прагматичного потенціалу висловлення: Монографія. Тернопіль: Підручники і посібники, 320.

4. Калита, А. А. (1984). Интонащия констатирующих высказываний в английской монологической и диалогической речи (Экспериментально-фонетическое исследование) (Дис. канд. филол. наук), Київ.

5. Цеплітис, Л. (1974). Анализ речевой интонаџии. Изд-во “Зинатне”.

6. Нушикян, Э. А. (1986). Типология интонации эмоциональной речи. Гол. изд-во издательского объединения "Выща школа".

7. Hayward K. (2013) Experimental Phonetics. Routledge (Taylor \& Francis Group). 